\title{
Articles
}

\section{Health Care Consumers: Choices and Constraints}

\author{
Catherine G. McLaughlin \\ University of Michigan
}

\begin{abstract}
This article summarizes the research and data currently available on different dimensions of consumer choice. These dimensions include not only whether to participate in a health care plan and which plan to select if given a choice but also the decisions that lead to having a choice and the implications of making the choice. Data are presented on what choices consumers face, how many are given what kinds of choices, what constraints they face, what we know about how they make these choices, and what information they are given and what they use. The majority of Americans are offered some kind of health insurance plan either through their place of employment or as a dependent on someone else's employer-sponsored health plan. About half of those offered health insurance are offered a choice, usually of only two or three plans. The majority elect to participate in one of those plans.
\end{abstract}

\section{INTRODUCTION}

What choices do health care consumers make? What constraints do they face? What information are consumers given with which to make these choices? How do they use this information in making their choices? By the time the average consumer leaves the provider's office, a long chain of decisions have been made that influence the selection of the provider, the treatment, and the coverage limits.

For some adults, the first choice that may in part be conditioned on an individual's desire for health insurance coverage is whether to enter the labor market, then what kind of firm in which to seek employment. Frequently discussed is the role played by Medicaid in the welfare/work decision. Lack of

S) Medical Care Research and Review, Vol. 56 Supplement 1, (1999) 24-59 (c) 1999 Sage Publications, Inc. 
affordable health insurance in the self-employed and small employer market may also influence spouses of workers in those markets to seek employment (McLaughlin and Zellers 1994). Almost 90 percent of insured individuals under age 65 obtain coverage from their employer or as dependents of a family member with group-sponsored health insurance (Long and Marquis 1993).

The decision of what kind of firm in which to seek employment is also influenced by the demand for health insurance. Health insurance options vary by firm. While health insurance is but one factor in firm choice, it is not difficult to believe that young, single males may deliberately choose to supply their labor to a small, high-tech firm that offers no health insurance in exchange for higher wages, and that a young male with similar skills but two small children and a wife who does not want to enter the labor market may instead supply his labor to IBM, earning a lower salary but receiving a rich family health insurance package at a large group rate.

The ability to search among firms within an industry according to health insurance offerings varies, however. A minority of skilled workers find themselves in an industry that is routinely redlined by health insurance companies, for example, high wire construction, asbestos removal, or beauty salons, making health insurance difficult to obtain and very expensive (Zellers, McLaughlin, and Frick 1992). Once an individual has acquired specific skills, it is sometimes difficult to move freely in the labor market. Those earlier choices may lead to constraints.

In addition to whether a firm offers health insurance, individuals may also care about the kind of health insurance that is offered, whether there is a choice of plans, whether the one plan offered is fee-for-service (FFS) or a health maintenance organization (HMO), or whether there is a high deductible plan offered. An employer can use health insurance options to influence the kind of worker seeking employment in that firm. For example, offering a subsidized family coverage benefit may discourage single workers and encourage young workers with families. A firm whose work requires risktaking may want to offer a high deductible plan, since those most likely to accept the job offer will be the risk takers. Most employers offer only one plan or a fairly limited number of plans from which to choose. Once the decision to work for a particular firm has taken place, the employee has closed the door to some choices that are no longer available.

For the individual who has elected to work for a firm with no health insurance offered, there are three options: seek coverage in the nongroup market (approximately 10.5 million Americans have individual coverage, accounting for 4.5 percent of the nonelderly population; U.S. General Accounting Office 
[GAO] 1996), obtain group coverage through another source (most commonly a spouse's plan), or self-insure.

Not all of those working for a firm that offers health insurance end up participating in one of those plans. First of all, not all employees are eligible for their firm's plans. Others will elect not to participate in any of the options presented for a variety of reasons: in some cases, they can get better coverage somewhere else, in others, they are unwilling to pay even the subsidized premium. Those who either are ineligible or elect not to participate in their firm's plan end up with the same choices as the individual who elected to work for a firm without any health insurance offerings.

For those who are eligible for their firm's plans and who have a choice, how do they make the choice? Once employees choose a health insurance plan, they are usually locked in that plan for up to a year until the next open enrollment period. Even then, inertia leads to little change, making the initial decision an important one. What information are they given? What information do they use?

It turns out that for many of us, the enrollment choice is an important one. Once enrolled in a particular plan, consumers are constrained by the specifics of the plan. The decisions about when to seek care and which provider to use are influenced by the type and financial incentives of the plan. The choice of treatment is also constrained by plan specifics. A person who would want every possible treatment known, whether experimental or well established, if faced with a life-threatening disease will want a different kind of plan than a person who is more conservative in treatment choice.

In some important ways, the individual who chooses to self-insure faces the least constraints; she is free to choose any willing provider. Of course, this freedom is greatly reduced for many by lack of money.

At this point, it is clear that these decisions at the endpoint work back through the other decisions. For example, the perceived need for freedom of choice of provider and treatment may reflect knowledge of medical need, which in turn influences the desire to enter the workforce to begin with. Always attached to any choice a consumer makes are the consequences of taking one option instead of the other. In many cases, when consumers make one choice, they are then shutting off other options and facing future constraints.

Given that caution, what do we know? A lot, and not very much. There are a lot of reported data. Data that tell us how many firms offer health insurance, how many workers choose to participate, how many choose FFS or HMOs. However, there is very little information about what the full set of choices and constraints are at each level, whether consumers were making choices under full information. It is difficult to interpret all of these data about distributions 
as revealing consumers' preferences. We really know very little about how and why consumers make the choices they make.

This article summarizes the research and data currently available on different dimensions of consumer choice, with the major focus on health insurance choice. While there have been studies of individual pieces of this puzzle, there has been no overarching conceptual model of what choices and constraints consumers face. This catalog of a wide array of surveys and studies presents data on what choices consumers face and are making along the way.

One cautionary note: this is not a critical interpretation of the validity of these data. The data collected and presented here come from surveys using a variety of sampling frames (some random, some not), asking different questions (some well written, some not), receiving different levels of response rates (some high, some low), and employing different, if any, tests for nonresponse bias, much less corrections for said bias. Doing such an evaluation was outside the scope of this article. A list of the major data sources used is included in the appendix, which gives, when available, whether a survey used a national sample, what size firms were included, and other relevant information. In some cases, reports did not even give the question asked or the origin of the sampling frame, much less the response rate or any biases. In summarizing the data, therefore, I try to focus on patterns found by multiple studies and on trends found over time by a consistent data source.

\section{CHOICE OF BENEFIT}

\section{HEALTH INSURANCE VERSUS OTHER BENEFITS}

There are no data that tell us whether workers sort themselves according to the availability of employer-sponsored health insurance. There is mixed evidence about the existence and extent of job lock, the influence of health insurance on staying at a worker's current job (Cooper and Monheit 1993; Gruber and Madrian 1993; Madrian 1993). There is no information on whether some uninsured workers would willingly trade wages or other fringe benefits for health insurance if they could get that insurance at a group rate. There is limited information on how much insured workers would need to be paid to give up coverage (Sherer 1993). Adding to the lack of information about sorting is the awareness that employers and employees alike are confused about who is actually paying for health insurance (Pauly 1997). To the extent that participation in benefit programs reveals consumer preference, we can look at data showing the distribution of benefits as an indication of consumer choice of benefits. 
By measures of participation and dollars spent, workers value health insurance. A 1993 Employee Benefit Research Institute (EBRI) survey of currently insured workers estimated that the average annual salary would have to increase by $\$ 4,570$ if health insurance were taken away (Sherer 1993). The response varied by age, income, and education. There are many different employee benefit programs, including paid holidays, vacations, and sick leave as well as long-term disability, dental, life, and medical insurance. Surveys of establishments by the Bureau of Labor Statistics (BLS) reveal that paid holidays and vacations had the highest levels of participation. However, only participation in life insurance ranks higher than participation in employmentsponsored medical care insurance for most workers. In 1995, 77 percent of full-time workers in firms with 100 or more employees participated in employer-sponsored medical care insurance, whereas 87 percent participated in an employee life insurance program (U.S. Department of Labor, BLS 1997).

According to Chamber of Commerce data, benefits as a percentage of payroll ranged from 18 percent to 60 percent, with the average equal to 41.3 percent (U.S. Chamber of Commerce 1994). Medical and medically related benefits were the largest single group of benefits, accounting for 26.7 percent of benefit dollars. On average, the cost of all health-related benefits, which includes contributions to premiums, to the Medicare Hospital Insurance Trust Fund, worker's comp, temporary disability insurance, and industrial plant health services, was $\$ 3,995$ and equaled 10.3 percent of payroll.

By these measures, workers value health benefits highly. However, workers are often ignorant of the full cost, in terms of wage growth, of these benefits (Pauly 1997). Therefore, these figures do not necessarily reveal worker preferences for health insurance versus wage increases. The offering of a flexible benefit or cafeteria-style plan, in which employees are given a fixed contribution to health care and other benefit costs, could potentially tell us at what rate employees would trade different benefits. By making workers more aware of the cost of each benefit, employers hope to improve choice, both of benefit plans and firms. Employers are also hoping to shift the burden of increases in the cost of health insurance to the employee (U.S. Chamber of Commerce 1994).

According to annual Chamber of Commerce surveys, the number of firms offering cafeteria-style plans increased from 14 percent in 1990 to 24 percent in 1993. Most of those who are offering these options are doing so as part of a health benefits cost containment effort. Fifty-two percent of the firms interviewed in a 1994 survey by Foster-Higgins said that they were offering a cafeteria-style plan in order to contain costs. Twenty-eight percent were doing it to satisfy diverse employee needs (EBRI 1995). 
Typically flexible benefit plans include two or more health plans and often one or more other benefits, such as dental coverage, group life insurance, and dependent care benefits (EBRI 1997). The most frequent flexible benefit plan is a reimbursement or flexible spending account (FSA) from which employees may be reimbursed with pretax dollars for out-of-pocket (OOP) expenditures on health care or dependent care. Larger firms are more likely to offer these, as are firms in the services industry. According to a 1993 Foster-Higgins survey, 43 percent of firms with 500 or more employees offered a health reimbursement account, whereas only 12 percent of those with fewer than 500 employees offered one (EBRI 1995). Thirty-eight percent of full-time workers in firms with 100 or more employees were eligible for a freestanding FSA versus 16 percent of those in small firms (U.S. Department of Labor, BLS 1997). Less common are "cafeteria" plans, or flexible spending programs. Twenty-three percent of firms with 500 or more employees offered a flexible spending program, and only 4 percent of the smaller firms did (EBRI 1995). Only 17 percent of full-time workers in firms with 100 or more employees were eligible for such a plan (U.S. Department of Labor, BLS 1997). The majority of full-time workers are not offered either a cafeteria plan or an FSA.

\section{THE OFFER OF HEALTH INSURANCE}

Although it may seem obvious, the first step toward getting employersponsored health insurance is for firms to make the decision to offer group health insurance to their workers, and often their dependents. Approximately 60 percent of all firms offer health insurance as a benefit. There is considerable variation in firm offer rates, particularly by size of firm and industry (Tables 1-4). These are differences that have been fairly constant over time (Lippert and Wicks 1991; Long and Marquis 1993; Cantor, Long, and Marquis 1995). Virtually all very large firms offer health insurance, whereas only 50 percent of the smallest firms do. The lower offer rate by small firms reflects a variety of labor and insurance market differences between small firms and large firms, including the larger loading fee added to small-group insurance rates (Brown, Hamilton, and Medoff 1990; McLaughlin and Zellers 1992).

The difference in coverage between the smallest firms and larger firms is so large that surveys, such as those conducted by the Chamber of Commerce, that don't make a special effort to represent the smallest firms in their sample and weight them appropriately tend to overstate the percentage of all firms offering health insurance. For example, the Chamber of Commerce surveys estimate that virtually all firms offer, whereas the BLS and Robert Wood Johnson Foundation (RWJF) surveys estimate closer to 60 percent offer (Table 1). 
30 MCRER 56 (Supplemental: Power of Choice, 1999)

TABLE 1 Percentage of Firms Offering Health Insurance, by Number of Employees $^{a}$

\begin{tabular}{|c|c|c|c|c|c|c|c|c|c|}
\hline & All & $<25$ & $<50$ & $25-99$ & $1-99$ & $50+$ & $100+$ & 100-999 & $1 K+$ \\
\hline $91 \mathrm{C}$ of $\mathrm{C}$ & 99 & & & & & & & & \\
\hline 91 HIAA & 40 & 32 & & 81 & & & & 95 & 98 \\
\hline 92-3 BLS & 58 & & & & 57 & & 80 & & \\
\hline $92 \mathrm{C}$ of $\mathrm{C}$ & 98 & & & & & & & & \\
\hline $93 \mathrm{C}$ of $\mathrm{C}$ & 98 & & & & & & & & \\
\hline 93 RWJF & 58 & & 50 & & & 93 & & & \\
\hline
\end{tabular}

Sources: U.S. Chamber of Commerce Research Center (1994); Sullivan et al. (1992); Bucci and Grant (1995); Cantor, Long, and Marquis (1995).

Note: HIAA = Health Insurance Association of America, BLS = Bureau of Labor Statistics, C of C = Chamber of Commerce, RWJF = Robert Wood Johnson Foundation.

a. In all tables, the size of firm is given by the number of employees. The inclusion of part-time employees varies across studies.

TABLE 2 Percentage of Small Firms Offering Health Insurance, by Number of Employees

\begin{tabular}{lllcccccc}
\hline Study & Year & $1-4$ & $5-9$ & $1-9$ & $10-24$ & $<25$ & $25-49$ & $<50$ \\
\hline HIAA & 1991 & & & 25 & 55 & 32 & 77 & 34 \\
HIAA & 1992 & & & 41 & 64 & & 83 & 50 \\
SBBS II & $1992-93$ & 46 & 68 & 55 & 83 & 60 & & \\
WSU / KPMG & 1993 & & & 44 & 70 & & 85 & 51 \\
RWJF & $1993-94$ & 33 & 52 & & 68 & & 82 & 50 \\
WSU / KPMG & 1995 & & & 50 & 66 & & 86 & 53 \\
KPMG & 1996 & & & 42 & 78 & & 90 & \\
\hline
\end{tabular}

Sources: Sullivan et al. (1992); Morrisey, Jensen, and Morlock (1994); McLaughlin and Zellers (1994); Cantor, Long, and Marquis (1995); Jensen and Morrisey (1997); Ginsburg, Gabel, and Hunt (1998).

Note: HIAA = Health Insurance Association of America, SBBS II = Small Business Benefit Study II, WSU /KPMG = Wayne State University /KPMG Peat Marwick, RWJF = Robert Wood Johnson Foundation.

Studies that have focused on the smallest firms reveal that a dramatic increase occurs at around 10 employees (Table 2). Because 80 percent of employers employ only 12 percent of the workforce, the lower offer rates among the smallest firms still result in an estimated 75 percent of all workers being offered health insurance through their place of employment (Table 3). 
TABLE 3 Percentage of Workers Offered Health Insurance, by Size of Firm and Worker Characteristics

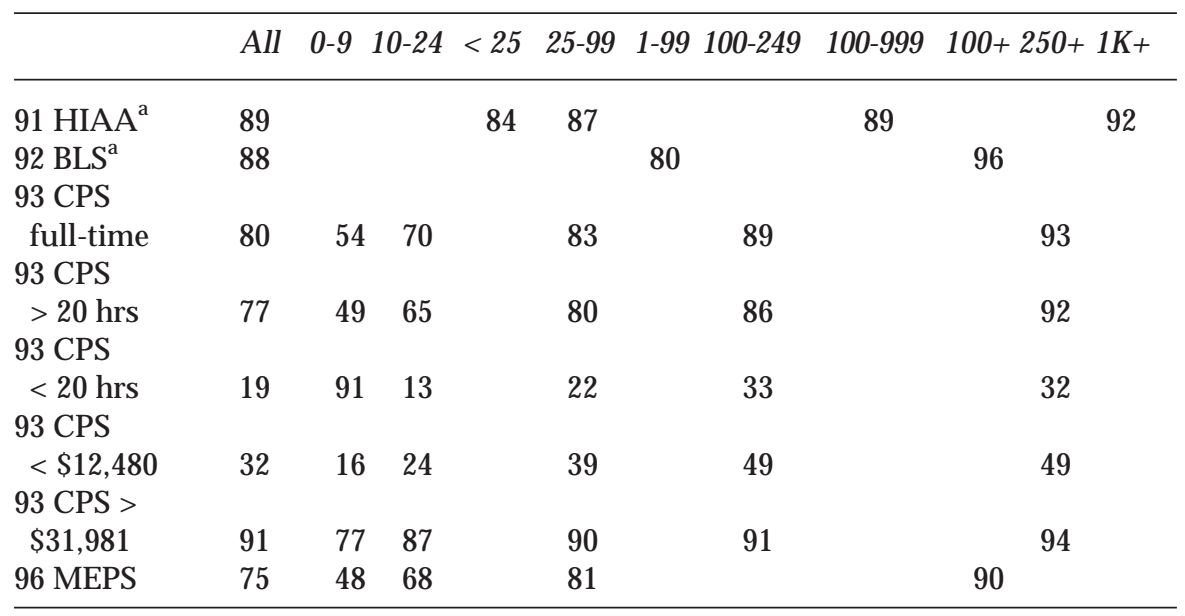

Sources: Sullivan et al. (1992); Bucci and Grant (1995); Nichols et al. (1997); Cooper and Steinberg Schone (1997).

Note: HIAA = Health Insurance Association of America, BLS = Bureau of Labor Statistics, CPS = Current Population Survey, MEPS = Medical Expenditure Panel Survey.

a. Prevalence includes only full time workers

TABLE 4 Percentage of Workers Offered Health Insurance, by Industry and Occupation, 1993 Current Population Survey

\begin{tabular}{lccccc}
\hline & All & White Collar & Clerical & Blue Collar & Service \\
\hline All & 70 & 84 & 71 & 68 & 45 \\
Agriculture & 36 & - & 38 & 32 & - \\
Retail trade & 50 & 74 & 57 & 54 & 25 \\
Construction & 56 & 86 & 66 & 49 & - \\
Services & 66 & 80 & 66 & 51 & 45 \\
Wholesale trade & 78 & 86 & 79 & 72 & - \\
Finance/insurance/ & & & & & \\
$\quad$ real estate & 79 & 87 & 76 & 63 & 64 \\
Transportation/utilities & 84 & 89 & 87 & 80 & 80 \\
Manufacturing & 85 & 94 & 87 & 81 & 67 \\
Mining & 89 & 99 & 95 & 83 & - \\
Public administration & 91 & 93 & 88 & 87 & 91 \\
\hline
\end{tabular}

Source: Nichols (1997).

Note: $-=$ too few observations. 
32 MCRER 56 (Supplemental: Power of Choice, 1999)

TABLE 5 Percentage of Workers Covered by Health Insurance, by Size of Firm

\begin{tabular}{lccccccccc}
\hline & All & $0-9$ & $10-24$ & $<25$ & $25-99$ & $100-249$ & $100-499$ & $250+$ & $500+$ \\
\hline 93 CPS & 84 & 70 & 78 & & 86 & 90 & & 94 & \\
93 CPS ESI & 74 & 52 & 62 & & 75 & 82 & & 90 & \\
93 CPS ESI own & 62 & 34 & 48 & & 63 & 72 & & 82 & \\
95 CPS & 82 & & & 70 & 80 & & 85 & & 88 \\
95 CPS ESI own & 55 & & & 31 & 54 & & 64 & & 68 \\
96 MEPS ESI & 73 & & & & & & & & \\
\hline
\end{tabular}

Sources: Nichols et al. (1997); Cooper and Steinberg Schone (1997); Fronstin (1997).

Note: CPS = Current Population Survey, ESI = employment-sponsored insurance, MEPS = Medical Expenditure Panel Survey.

a. Employer-sponsored insurance, either through spouse or own employer.

TABLE 6 Percentage of Nonelderly Population with and without EmploymentBased Health Insurance, by Industry; 95Current Population Survey

\begin{tabular}{|c|c|c|c|}
\hline & Employment-Based & $\begin{array}{c}\text { Individually } \\
\text { Purchased }\end{array}$ & Uninsured \\
\hline Agriculture & 45 & 17 & 33 \\
\hline Personal services & 51 & 8 & 32 \\
\hline Construction & 56 & 7 & 33 \\
\hline Business and repair services & 60 & 7 & 27 \\
\hline Retail trade & 63 & 5 & 26 \\
\hline Entertainment and recreation services & 67 & 7 & 22 \\
\hline Wholesale trade & 78 & 5 & 15 \\
\hline Manufacturing: nondurable goods & 80 & 2 & 15 \\
\hline $\begin{array}{l}\text { Transportation, communication, } \\
\text { public utilities }\end{array}$ & 81 & 3 & 14 \\
\hline Finance, insurance, real estate & 82 & 5 & 11 \\
\hline Professional and related services & 82 & 4 & 11 \\
\hline Public administration & 82 & 1 & 4 \\
\hline Mining & 84 & 2 & 12 \\
\hline Manufacturing: durable goods & 85 & 2 & 12 \\
\hline
\end{tabular}

Source: U.S. General Accounting Office (GAO) (1996).

Note: The rows do not total 100 percent because public insurance coverage is not included. 
TABLE 7 Percentage of Nonelderly Population with and without EmploymentBased Health Insurance, by Select Worker Characteristics; 95 Current Population Survey

\begin{tabular}{lccc}
\hline & & Individually & \\
& Employment-Based & Purchased & Uninsured \\
\hline U.S. average & 65 & 4 & 18 \\
<20 years old & 62 & 4 & 15 \\
$20-29$ years & 58 & 3 & 28 \\
$30-39$ & 69 & 4 & 18 \\
$40-49$ & 74 & 5 & 15 \\
$50-59$ & 71 & 6 & 14 \\
$60-64$ & 62 & 10 & 15 \\
Retired, $<65$ & 59 & 10 & 16 \\
White & 72 & 5 & 14 \\
Black & 49 & 2 & 22 \\
Hispanic & 41 & 2 & 36 \\
Below poverty level & 18 & 4 & 32 \\
At, above poverty level & 74 & 5 & 15 \\
Full time, full year & 80 & 4 & 14 \\
Full time, part year & 60 & 4 & 28 \\
Part time, full year & 64 & 8 & 23 \\
Part time, part year & 59 & 7 & 24 \\
Unemployed & 40 & 6 & 24 \\
Self-employed & & 20 & \\
\hline
\end{tabular}

Source: U.S. General Accounting Office (GAO) (1996).

Note: The rows do not total 100 percent because Medicaid, Medicare, and Civilian Health and Medical Program of the Uniformed Services (CHAMPUS) are not included.

Not all workers in a firm are offered the firm's group insurance. For example, few offer insurance to their temporary or part-time (PT) workers. The Chamber of Commerce reports that only 22 percent of their respondents offered health insurance to PT workers (U.S. Chamber of Commerce 1994). The 1991 Health Insurance Association of America (HIAA) survey, which included more small firms than the Chamber of Commerce survey, found that, on average, only 14 percent of PT workers were eligible for their firm's plan. Analysis of the 1993 Current Population Survey (CPS) data shows that while 80 percent of full-time (FT) workers are offered insurance, only 19 percent of those working fewer than 20 hours a week are (Table 3). Even this difference is mitigated by the size of the firm, with more PT workers offered health insurance by larger firms. In firms with 100 or more workers, the 
percentage of those working at least half-time offered health insurance is virtually the same as that of FT workers. A worker's salary also influences whether or not she or he will be offered health insurance. Higher-paid workers are much more likely to be offered health insurance. Forty-three percent of workers earning less than $\$ 7$ per hour are offered health insurance by their employer, whereas 93 percent of those earning more than $\$ 15$ per hour are offered coverage (Cooper and Steinberg Schone 1997). Once again, this difference narrows as the size of firm increases (Bucci and Grant 1995). Younger workers are also less likely to be offered health insurance-only 51 percent of those younger than 25 years of age are offered coverage (Cooper and Steinberg Schone 1997).

The percentage of workers offered health insurance also varies by industry and occupation (Table 4). Only one third of agricultural workers are offered insurance, and one half of those in retail trade or construction, reflecting in part the prevalence of small firms within these industries as well as the insurance industry's medical underwriting procedures (Zellers, McLaughlin, and Frick 1992). Public administration, mining, manufacturing, and transportation and utilities have the highest offer rates, 84 to 91 percent. These industries are more likely to have a unionized workforce, a factor found to be correlated with the offer of health insurance (Long and Marquis 1993; Cantor, Long, and Marquis 1995). The industry variation also reflects the composition of the workforce. Eighty-four percent of white-collar workers are offered insurance, but only 45 percent of service workers are.

\section{Why Do Employers Choose Not to Offer Health Insurance?}

Dollars are the number one reason why firms choose not to offer health insurance to their workers. Although particularly true for small firms, over time, in various surveys, high and rising premiums are cited as the main reason for not offering health insurance by large and small employers alike ( Lippert and Wicks 1991; McLaughlin and Zellers 1992; Morrisey, Jensen, and Morlock 1994). A 1995 survey by Arthur Anderson of small and mid-sized businesses indicated that owners felt that the cost of benefits was one of the biggest obstacles to their future growth and survival (Employers 1996). Premiums for midsize businesses increased an average of 6 percent over 12 months, but small companies, those with fewer than 20 employees, reported a 10 percent average premium increase during the same time span. A GAO report estimated that, because of different loading factors and, in some cases, differential risk, premiums for small businesses were 10-40 percent higher than premiums for equivalent insurance plans offered to large businesses 
(GAO 1992). In their surveys of small businesses, both McLaughlin and Zellers (1992) and Morrisey, Jensen, and Morlock (1994) found that premiums, premium increases, and the impact on profits were dominant determinants of a small firm deciding not to offer insurance.

In addition to affordability, these two studies of small businesses also found that availability and attitudes played a role. Specifically, medical underwriting procedures, eligibility based both on redlining and preexisting conditions, may result in some small firms not qualifying for many health insurance plans. A more common reason, however, for not offering, both for small and large firms, is lack of interest. McLaughlin and Zellers (1994) found that over 60 percent of the small businesses in their survey who did not offer health insurance were not interested in offering it. The employer's perception of worker preferences as well as experience in being able to recruit and retain workers with desired qualities lead to this lack of interest. Approximately one fourth of the firms surveyed in 1990 by HIAA (Lippert and Wicks 1991), one third of the small firms surveyed in 1993 by HIAA (Morrisey, Jensen, and Morlock 1994), and one third to one half of the small firms surveyed in 1993 by McLaughlin and Zellers (1994) said that worker preferences, particularly for higher wages, were very important reasons for not offering health insurance. These responses suggest these employers do recognize that employees usually bear the cost of insurance and are offering the compensation package necessary to attract and keep the workers with skills that they need.

Why do some of these workers not want health insurance? Some, particularly those with lower incomes, may prefer higher wages to having health insurance. The so-called young invincibles may not value health insurance very highly, seeing the trade of wages for insurance as a bad deal in the short term. For some of these workers, the availability of health insurance at lower large-group rates through a spouse's employer is a major reason. McLaughlin and Zellers (1994) found that approximately one half of the employers chose not to offer health insurance because their workers already had insurance from another source, usually their spouse's employment-based insurance. In fact, in small firms where employers said that their employees' ability to get insurance elsewhere was a very important reason why they did not offer health insurance, 73 percent of the employees did obtain insurance from another source; in firms where this was not important to the decision not to offer, only 34 percent of employees had insurance from another source.

Do we have any evidence then that workers are self-sorting; that is, choosing to work for firms that do not offer health insurance because they are unwilling to trade wages for health insurance? There is some evidence of selfsorting among some workers. We know that lower-wage workers are less 
likely to be offered health insurance and that very young workers are less likely to be offered health insurance. However, these kinds of workers are also more likely to be working for smaller firms, which are faced with higher premiums, lower profit margins, and more medical underwriting. Coupled with industry and occupation differences, these differences make it difficult to interpret the distribution of workers as evidence that workers are self-sorting. However, in their analysis of the 1988 CPS data, Long and Marquis (1993) found that employees who were offered but turned down employersponsored insurance were very similar in measured characteristics (wage, hours worked, age, gender, family status, firm size) to those working in firms that do not offer.

\section{PREVALENCE OF WORKER COVERAGE}

Consistent with the earlier observed differences in firm offer rates, the prevalence of worker coverage varies, both by firm and worker characteristics (Tables 5-7). Some of the patterns are repeated. Workers employed by larger firms are more likely to be covered by health insurance (Table 5). Workers in manufacturing, mining, and public administration are more likely to be covered; those in agriculture and construction are less likely to be covered (Table 6). Full-time workers and highly paid workers are more likely to be covered (Table 7). Coverage rates for most workers are decreasing, however. For example, the percentage of FT employees covered decreased from 1992/93 to $1994 / 95$ for all sizes of private establishments, from 71 percent to 66 percent in small establishments and 82 percent to 77 percent in medium and large establishments; the percentage of PT workers in state and local governments covered decreased from 43 percent to 31 percent over the same time period (U.S. Department of Labor, BLS 1994, 1996, 1997).

These comparisons are somewhat misleading, however, because not all of these workers are getting employment-based insurance through their own employer. For example, 45 percent of agricultural workers have employmentbased insurance and yet only 36 percent are offered health insurance (Tables 6 and 4). The difference is that some of these workers are included as dependents on their spouse's employer-sponsored insurance. Analysis of the 1993 CPS data reveals that 84 percent of workers were covered by health insurance, 74 percent were covered by employment-sponsored insurance, and only 62 percent were covered by insurance sponsored by their own employer (Table 5). In 1993, close to 12 million workers, 17 percent of the workforce, were covered by their spouse's employer's health insurance plan (EBRI 1997). This figure includes both workers in firms that did not offer insurance and those who work for firms that do offer insurance, but who chose to turn it down. 
TABLE 8 Reasons for Being Ineligible or Denied Health Benefits or for Choosing Not to Participate; 1993 Current Population Survey (percentages)

\begin{tabular}{|c|c|c|c|}
\hline & All Workers & $\begin{array}{l}\text { Ineligible } \\
\text { or Denied }\end{array}$ & $\begin{array}{l}\text { Choose } \\
\text { Not to }\end{array}$ \\
\hline Ineligible or denied & $5^{\mathrm{a}}$ & 100 & \\
\hline Probationary period not over & & 28 & \\
\hline Contract or temporary & & 9 & \\
\hline Part-time & & 61 & \\
\hline Preexisting condition & & 2 & \\
\hline Choose not to participate $^{\mathrm{b}}$ & $8^{\mathrm{a}}$ & & \\
\hline Other coverage & & & 75 \\
\hline Plan too costly & & & 23 \\
\hline Too many limitations & & & 2 \\
\hline Don't need/want coverage & & & 6 \\
\hline Other reason for not participating & 2 & & \\
\hline
\end{tabular}

Source: Yakoboski et al. (1994).

a. 5 percent of all workers are employed by firms that offer health insurance but are ineligible or denied health benefits; 8 percent of all workers are eligible but choose not to participate.

b. Workers can list more than one reason.

The difference between the percentage covered by employer-sponsored insurance and that covered through their own employer decreases as the size of firm increases. In other words, employees of small businesses are more likely to get insurance through a spouse's employment-based insurance policy. As mentioned before, this tendency may reflect the higher premiums charged to small businesses for similar insurance packages. More highly paid workers (82 percent of those earning $\$ 40,000$ or more vs. 17 percent of those earning less than $\$ 10,000$ ) and FT workers (63 percent vs. 20 percent of PT workers) are also more likely to get employer-sponsored insurance on their own (EBRI 1997).

In addition, workers are not always eligible for their firm-sponsored plan. Five percent of workers in firms that offer insurance, approximately 6 million workers, are not eligible (Table 8) (Yakoboski et al. 1994). A fourth of these are new hires who have not passed the probationary period. Almost 70 percent are ineligible because of work status, either PT workers (61 percent) or temporary and contract workers (9 percent). The lowest paid are more likely to be in this category (Yakoboski et al. 1994). Only 2 percent are ineligible because of preexisting conditions. 
TABLE 9 Percentage of Eligible Workers Enrolled in Firm's Plan, by Size of Firm

\begin{tabular}{lcccccccc}
\hline & All & $<25$ & $25-99$ & $100-249$ & $100-999$ & $100+$ & $250+$ & $1 \mathrm{~K}+$ \\
\hline 91 HIAA full time & 84 & 84 & 83 & & 81 & & & 88 \\
91 HIAA part time & 55 & 34 & 49 & & 53 & & & 62 \\
93 CPS & 88 & 83 & 86 & 93 & & & 88 & \\
93 SBBS full time & & 74 & & & & & & \\
93 SBBS part time & & 50 & & & & 84 & \\
96 MEPS & 80 & 74 & 79 & & & 84 \\
\hline
\end{tabular}

Sources: Sullivan et al. (1992); Nichols et al. (1997); McLaughlin and Zellers (1994); Cooper and Steinberg Schone (1997).

Note: HIAA = Health Insurance Association of America, CPS = Current Population Survey, SBBS = Small Business Benefit Study, MEPS = Medical Expenditure Panel Survey.

\section{Why Do Employees Choose Not to Participate When Given a Choice?}

Of those eligible, 80 percent take the offer and participate (Table 9). All other things being equal, if workers were able to sort according to the offering of health insurance, the percentage of workers offered health insurance and the percentage of workers covered by employment-based insurance would be the same. That is, the take-up rate would be 100 percent-all workers offered health insurance would participate. Unfortunately, all other things are not equal. Jobs vary by more than the offering of health insurance. For example, young single assembly line workers may not be able to find equivalent work in firms that do not offer health insurance. When given the choice, they may opt out of paying the OOP premium, go without health insurance, and try to negotiate a higher wage.

A recent study comparing 1989 and 1996 household surveys reveals that more and more workers, particularly low-wage workers, are declining to take employer-sponsored insurance (Cooper and Steinberg Schone 1997). The two dominant factors that seem to influence an employee's decision to choose not to participate in an employer-sponsored insurance plan are cost and availability of a better value through another source, usually a spouse's employer, consistent with the reasons given by employers for not offering health insurance. According to the 1996 national survey, 80 percent of those offered a plan choose to participate. In contrast, only 63 percent of those earning less than $\$ 7$ per hour who are offered coverage choose to participate; and fewer than half of those working part-time, 70 percent of those under age 25 , and 74 percent of 
those working in firms with fewer than 25 employees who are offered coverage choose to participate (Cooper and Steinberg Schone 1997). Comparing 1989 and 1996 data on firms with fewer than 200 employees, Ginsburg, Gabel, and Hunt (1998) found a similar trend. Whereas 72 percent of the employees were enrolled in a firm-sponsored plan in 1989, only 66 percent were enrolled in 1996.

Of those who just say no, 75 percent have other group coverage, usually through a spouse's plan (Yakoboski et al. 1994). Analysis of the 1993 CPS data revealed that women were more likely to choose not to participate (Yakoboski et al. 1994). Buchmueller (1996) found that men who work full-time are more likely to receive employer-sponsored health insurance than women who work full-time. According to his analysis, this gap is driven largely by the tendency of married women to decline employer-sponsored insurance in favor of being covered through their husband's employer's insurance policy. In the Federal Employees Health Benefit Plan (FEHBP), 28 percent of employees and retirees are either not eligible or choose not to participate (Evans 1995). Most of those who choose not to participate have coverage through a spouse or Medicare.

Overall, 18 percent of nonelderly workers go bare (Fronstin 1997). Those with no coverage are more likely to be employed by small firms-31 percent of those working for firms with fewer than 25 employees versus 12 percent of those working in firms with 500 or more (EBRI 1997). They also are younger, lower-wage (30 percent of those earning less than $\$ 10,000$ per year vs. 5 percent of those earning more than $\$ 40,000$ ), and PT workers (EBRI 1997). Four percent of workers do want insurance and purchase it in the individual market (Yakoboski et al. 1994). Those in small firms are more likely to enter the individual market, indicating a larger problem with self-sorting for these workers.

\section{CHOICE OF PLAN}

\section{AVAILABILITY OF CHOICE}

For many workers, the choice of employer determines the choice of plan. Although the percentage of firms offering more than one health care plan is increasing, it is still the case that the vast majority of all firms offer only one plan (Table 10). There are large administrative costs to offering more than one plan.

Just as being offered any plan varies by firm size and worker salary, so does the availability of choice. The percentage of firms offering more than one plan 
TABLE 10 Percentage of Firms Offering Choice, by Size of Firm

\begin{tabular}{|c|c|c|c|c|c|c|c|c|c|c|c|}
\hline & All & $<10$ & $10-49$ & $1-49$ & $50-99$ & $1-99$ & $50+$ & $100+$ & 200-999 & $1 K-4,999$ & $5 K+$ \\
\hline 92-3 BLS & 14 & & & & & 10 & & 52 & & & \\
\hline 93 RWJF & 22 & & & 14 & & & 40 & & & & \\
\hline 95 KPMG & $60^{\mathrm{a}}$ & & & & & & & & 55 & 76 & 90 \\
\hline 97 RWJF & 17 & 7 & 12 & & 19 & & & 32 & & & \\
\hline
\end{tabular}

Sources: Bucci and Grant (1995); Cantor, Long, and Marquis (1995); Health Benefits (1997); Long and Marquis (1998).

Note: BLS = Bureau of Labor Statistics, RWJF = Robert Wood Johnson Foundation, KPMG = KPMG Peat Marwick.

a. Survey does not include firms with fewer than 200 employees. 
increases with firm size, as low as 10 percent of firms with fewer than 100 employees and rising to 90 percent of firms with 5,000 or more employees. A 1996 KPMG survey found that only 9 percent of employees of firms with fewer than 10 employees were offered a choice of plans, whereas 54 percent of employees of firms with more than 200 employees were offered a choice (Gabel, Ginsburg, and Hunt 1997). The 1996 Kaiser/ Agency for Health Care Policy and Research (AHCPR) survey estimated that, overall, 55 percent of workers were offered a choice of plans at the workplace (Table 11). However, only the majority of higher-paid workers were offered a choice. Fifty-one percent of those earning \$15-\$20 an hour and 60 percent of those earning more than $\$ 20$ an hour were offered a choice of plans, whereas only 17 percent of workers earning less than $\$ 6$ per hour and 26 percent of those earning $\$ 6-\$ 10$ per hour were (Johnson and Crystal 1997). An earlier Kaiser/Commonwealth survey found that while 52 percent of the sample were offered a choice, only 40 percent of those in firms with fewer than 250 employees and 36 percent of those with an income of $\$ 15,000$ or less were offered more than one plan (Davis et al., Health Insurance, 1995).

Of those firms that offer a choice, the majority offer a choice between two plans (Table 12). About one fifth offer a choice between three plans, and a few offer more than three plans from which to choose. About half of all workers with choice are offered two plans, a fifth are offered three plans, and the rest four or more. Again, the tendency to offer multiple plans increases with firm size. A 1997 Mercer survey estimated that 56 percent of companies with 3,000 or more employees offer three or four plan types (Mercer Fax Facts 1997).

What is the optimal amount of choice? Although most firms that offer choice offer at least one indemnity, or FFS, plan and one managed care plan, a 1994 Commonwealth survey of managed care enrollees reported that 29 percent of these enrollees did not have the option to choose an FFS plan (Davis et al., Choice Matters, 1995). In general, these enrollees were less satisfied with their plan than those with a choice. A 1997 nationwide survey found similar results (Gawande et al. 1998).

At the same time, constraining choice to two or three options may actually benefit workers. Perhaps the one employee group with most choice are federal employees participating in FEHP. There are 4 million active employees and retirees, representing 9 million family members, who make a choice among two to three dozen plans each year. Schoen and Zacharis (1994) discuss "the illusion of choice" faced by FEHP enrollees. Although choice is supposed to improve member satisfaction, they report that a 1989 survey revealed that members have not been satisfied, that members would prefer fewer plans and less complexity. In general, members felt that they lack needed information 
TABLE 11 Percentage of Workers Offered Choice of Plans, by Size of Firm

\begin{tabular}{|c|c|c|c|c|c|c|c|c|c|c|c|c|c|c|c|}
\hline & All & $1-4$ & $5-14$ & $15-24$ & $25-99$ & $1-99$ & $100-249$ & $100-499$ & $100+$ & $500+$ & 200-999 & 250-999 & $1000+$ & $1,000-4,999$ & $5 K+$ \\
\hline 92-3 BLS & 46 & & & & & 22 & & & 69 & & & & & & \\
\hline 93 Kaiser & 52 & & & & & 38 & 40 & & & & & 46 & 67 & & \\
\hline 93/95 HRS & 42 & 14 & $4 \quad 10$ & 26 & 22 & & & 33 & & 52 & & & & & \\
\hline 95 KPMG & $85^{\mathrm{a}}$ & & & & & & & & & & 64 & & & 79 & 96 \\
\hline 96 Kaiser & 55 & & & & & & & & & & & & & & \\
\hline
\end{tabular}

Sources: Bucci and Grant (1995); Davis et al., Health Insurance (1995); Johnson and Crystal (1997); Health Benefits (1997); Hunt et al. (1997). Note: BLS = Bureau of Labor Statistics, HRS = Health and Retirement Survey, KPMG = KPMG Peat Marwick.

a. Survey does not include firms with fewer than 200 employees.

TABLE 12 Percentage of Firms that Offer and Percentage of FT Workers Offered Coverage, by Number of Plans Offered

\begin{tabular}{|c|c|c|c|c|c|c|}
\hline & \multicolumn{4}{|c|}{ Percentage of Firms } & \multicolumn{2}{|c|}{ Percentage of Full-Time Workers } \\
\hline & $\begin{array}{l}93 \text { RWJF, } \\
\text { Self-Insured }\end{array}$ & $\begin{array}{c}93 \text { RWJF, } \\
\text { Fully Insured }\end{array}$ & $92-93 B L S<100$ & 92-93 BLS 100+ & $\begin{array}{l}92-93 \text { BLS } \\
\quad<100\end{array}$ & $\begin{array}{c}92-93 \text { BLS } \\
100+\end{array}$ \\
\hline One & 36 & 60 & 89 & 48 & 77 & 31 \\
\hline Two & 24 & 23 & 9 & 29 & 15 & 27 \\
\hline Three+ & 40 & 17 & & & & \\
\hline Three & & & 2 & 11 & 4 & 13 \\
\hline Four & & & & 8 & 4 & 9 \\
\hline Five & & & & 2 & 0 & 6 \\
\hline Six & & & & 1 & 0 & 6 \\
\hline Six + & & & & 1 & 0 & 7 \\
\hline
\end{tabular}

Source: Acs et al. (1996); Sullivan et al. (1992); Bucci and Grant (1995).

Note: RWJF = Robert Wood Johnson Foundation, BLS = Bureau of Labor Statistics. 
about quality and subtle restrictions, that the number of plans makes side-byside comparisons of benefits too costly and complex.

\section{How Do Employers Make Their Choice?}

In theory, employers choose plans as agents for their employees, looking for attributes that their employees would prefer at good prices. In practice, employers are agents for stockholders as well, and in most surveys cost remains the most crucial consideration when employers choose health coverage for their workers (Mercer's Fax Facts 1997). In an American Management Association survey of more than 1,100 benefits managers, the cost to the company was ranked the most important of six factors. Its average score (on a 5point scale) was 4.68 (Cost Cuts Now 1996). If employers can offer a lower-cost plan that provides a similar scope of benefits, then the savings will not necessarily be passed on to the workers in the form of higher wages.

Of interest is how those lower costs are achieved by the plan, whether through efficiencies or lowering of the quality of care provided, and whether employers make their choice of offering a lower-cost plan while controlling for quality differences. In a KPMG 1997 survey, only 40 percent of employers deemed the National Committee for Quality Assurance (NCQA) accreditation as either very or somewhat important in their choice; 95 percent regarded price of plan or speed and accuracy of claims payment as very or somewhat important (Getting What You Pay For 1997). While more than two thirds of firms give their employees information about the costs of plans, fewer than 10 percent even give their employees information about accreditation or other quality measures.

Managed care organizations and health care providers clearly perceive that employers continue to focus more on price than quality when making health plan purchasing decisions, and thus initiating quality measurement and reporting programs is not a top priority of providers or managed care companies. In a 1993 Foster Higgins survey of 102 managed care organizations and 127 health care providers on their perceptions of the marketplace, over two thirds of them ranked price the most important factor for success in the marketplace, only 20 percent consider a quality improvement process important, and only 10 percent consider clinical guidelines and protocols or published outcomes important (Bergman 1994). However, as Margaret O'Kane, president of NCQA, pointed out, there is a bit of a chicken or egg problem here. Benefit managers may not value quality measures as highly because there is so little reliable data on quality available. These sentiments were echoed by the purchaser representatives of 33 large employers interviewed by Hibbard et al. 
(1997). Many questioned both the reliability and relevance of the data on quality that they received.

\section{How Do Employees Make Their Choice?}

Consistent with the data employers provide and the reasons they give for making their choice, corporate executives report that cost is the most frequently requested information by their employees (Getting What You Pay For 1997). Interestingly, when employees are surveyed about reasons for choosing a medical plan, they focus on issues of choice (Blankenau 1993), quality (Isaacs 1996; Robinson and Brodie 1997), and benefits covered (Tumlinson et al. 1997). As a representative from a large northeastern financial services firm said, "The number one thing people ask ... when they're considering an HMO is not like 'gee, am I going to get that mammogram,' it's 'What if I get sick, am I going to die, are they going to take care of me?' " (GAO 1995).

How do we resolve these inconsistencies? Many analysts rely on theoretical models; others, on the choices made. As David Mechanic (1989) summarized the dilemma, "For the past 25 years, health services researchers have tried to predict how consumers choose among health options, but with only modest success. The evidence suggests that assumptions of rationality accurately reflect how most people approach these decisions, but the real constraints on rational choice are so large that many simply opt out. The information typically informing choice is restricted, the plans vary on so many dimensions that comparisons are difficult to make, and the marketing literature confuses ideal statements with real operational performance" (p. 145).

Several conclusions can be made from a review of the data and relevant research (Scanlon, Chernew, and Lave 1997). One is that price does matter. Several studies have shown that employees are sensitive to OOP premiums (e.g., Schuttinga, Falik, and Steinwald 1985; Feldman et al. 1989; Francis 1995; and Buchmueller and Feldstein 1997). It should be noted that in many of these cases, there was a large change in OOP premium for comparable plans that had been around for a long time.

Second, employees will switch plans to respond to changed medical care needs. Robinson, Gardner, and Luft (1993) analyzed health plan switching by employees of a large private employer from 1982 to 1984. They found that these employees switched health plans when anticipating increased needs for maternity care. This is an anticipated utilization change that is somewhat under the control of the enrollee and therefore can be used to make plan choices. 
Third, to date report cards and other Health Plan Employer Data and Information Set (HEDIS)-like information has not been shown to have a significant influence on plan choice (Chernew and Scanlon 1998). Rather than indicating that employees do not care about the quality of a plan, this apparent lack of influence may reflect that employees do not find these data useful or unbiased (Hibbard and Jewitt 1996).

Fourth, there is a great deal of inertia. The factors that influence a new hire's choice of plan may differ from those that influence a current employee to switch (Neipp and Zeckhauser 1985). In particular, older workers and those with chronic conditions are less likely to be responsive to changes in OOP price or other financial incentives (Ellis 1989; Schoen and Zacharis 1994; Schweitzer, Hershey, and Asch 1996; Buchmueller and Feldstein 1997). In the Commonwealth survey, researchers found that older workers were more likely to stick with FFS - 26 percent had been in the same plan for 10 years or longer (Davis et al., Choice Matters, 1995). Blankenau (1993) reports that only 15 percent of enrollees in the Federal Employees Health Benefits Program (FEHB) consider switching coverage over a 10 -year period and that the program's retirees are the least interested in changing.

Fifth, there is some self-sorting by plan characteristics. In the Commonwealth survey, those who chose managed care plans were younger families (a) less likely to have an established relationship with an FFS physician, (b) more likely to have a lower income and therefore be more sensitive to OOP costs, and (c) more likely to prefer comprehensive preventive care services (Davis et al., Choice Matters, 1995).

Finally, there is a need for information to make a choice (Mechanic, Ettel, and Davis 1990; Wilensky 1995). In the absence of little objective information, workers are often making choices based on misconceptions of how plans operate and of their established physician-patient relationships. There are large transaction costs in obtaining information, synthesizing, understanding, and using or rejecting it. In a study of new employees, most new employees chose one of two well-known plans-a Blue Cross/Blue Shield plan and a large established HMO (Mechanic, Ettel, and Davis 1990). Despite a wide range of choices (14 options), 83 percent chose one of these two.

\section{Information Employees Are Using to Make a Choice}

Information typically shared with employees focuses on cost and administrative issues. A Washington Business Group on Health survey of 368 companies revealed that only 59 percent of employers with 10,000 or more 
employees, 23 percent with 1,000 to 9,999 employees, and 6 percent with fewer than 1,000 employees even use HEDIS in their decision making (Larger Firms Most Concerned 1996). Few share these data with their employees. Although Tumlinson et al. (1997) found that employees considered information on nonprice attributes important, it is not clear how much of the information employees are receiving can be processed and used.

Mechanic, Ettel, and Davis (1990) found that employees choosing the Blue Cross and Blue Shield plan were fairly knowledgeable about the ability to choose a provider in that plan, but there was less agreement on whether there were low deductibles or coinsurance rates. In contrast, for those choosing the $\mathrm{HMO}$ option, there was consensus on paperwork, knowing costs in advance, and deductibles and coinsurance, but a significant proportion were ignorant of choice constraints, believing they could see a specialist without referral, choose any hospital, and did not need prior authorization to see a physician out of town. Garnick et al. (1993) found similar problems with knowledge in a New York pilot program. People were uncertain about what services their plan covers and restrictions on their choice of hospitals.

Isaacs (1996) reports that in a 1995 Harris survey, 11 percent of the respondents were not sure how to characterize their plans (FFS, HMO, or preferred provider organization [PPO]); 63 percent said they did not have a good understanding of the differences between traditional FFS and managed care plans. Nearly one third had never heard the term health maintenance organization or had heard it but did not know what it meant; 55 percent had never heard the term managed care or did not know what it meant; 77 percent expressed the same lack of knowledge for the term fee-for-service. Thirty percent were not confident that they had the information needed to make a good choice of health plan.

And, finally, although whether or not the plan provides high-quality care was the most important concern in choosing for 42 percent of the respondents in the Kaiser/AHCPR survey, few respondents used this information in their own health care decision making (Robinson and Brodie 1997). Half of the respondents considered family and friends a very believable source on provider quality and turned to these sources when making their decision. This finding is consistent with the results of the study by Hoerger and Howard (1995) on the search for a prenatal care provider. They found very little search by expectant mothers. Even though 88 percent of those studied felt they had a choice of physician, fewer than 25 percent seriously considered more than one physician and fewer than 60 percent of them actually spoke to or visited a second physician. Instead, these women relied most heavily on information from friends and acquaintances. Given search costs, if friends and family share an 
individual's preferences, this may be an efficient way to choose. Friends and family may not be qualified, however, to judge technical quality.

\section{TYPES OF PLANS BEING OFFERED}

What do we know about the choices employees are facing and have made? Although the numbers are decreasing, the majority of firms offer an FFS plan (Table 13). About half of all employees are offered an FFS plan (Cantor, Long, and Marquis 1995; Health Benefits 1997). Increasingly, firms are offering a managed care plan, with much of the growth in the offering of a point-ofservice (POS) plan, although this remains an option mainly in the largest firms. Smaller firms are more likely to offer an FFS plan only (Table 14). While few employees are offered only an HMO or a PPO, almost 50 percent of workers were offered only an FFS plan in 1993. Given the increase in the offering of a POS plan reported by Mercer and KPMG, this figure has likely decreased during the last 5 years. The 1997 KPMG survey found that 42 percent of employees were offered a POS plan (Health Benefits 1997).

How do workers divide into these options? There is in general an increase in the percentage covered by some form of "managed care" and a corresponding decrease in the percentage with conventional coverage (Jensen et al. 1997). According to the BLS surveys, 86 percent of participants were enrolled in health plans with some kind of managed care provision, defined as "measures aimed at controlling health care costs and usage" (U.S. Department of Labor, BLS 1997). The Chamber of Commerce (1994) reports a trend in increasing preadmission certification, requiring second surgical opinion, limited patient choice of physicians, and other cost-sharing measures added to FFS plans.

Enrollment in FFS plans is decreasing, and enrollment in HMOs, PPOs, and POS plans is increasing (Tables 15 and 16). Although the level of participation in FFS plans is higher among small firms (55 percent of FT workers in firms with fewer than 100 employees in 1994 vs. 37 percent in medium and large firms in 1995; U.S. Department of Labor, BLS 1997), movement away from FFS plans is seen for small and large firms, private and public institutions (U.S. Department of Labor, BLS 1996, 1997; Jensen et al. 1997). According to a 1997 Mercer survey, when offered both an FFS and an HMO plan, the majority of workers chose the HMO; when offered an FFS and a PPO plan, almost three fourths chose the PPO; and when offered an FFS and a POS plan, over 80 percent chose the POS plan (Table 17). Some of these choices reflect preferences for less paperwork, lower OOP payments, ability to go out of network, and other plan characteristics; some of the decisions reflect response to differential employer premium subsidies. 
TABLE 13 Percentage of Firms or Establishments Offering, by Plan Type

\begin{tabular}{lccccccccccc}
\hline & & $\begin{array}{c}\text { Chamber of } \\
\text { FH 92 }\end{array}$ & $\begin{array}{c}\text { BLS } \\
\text { Commerce 92 }\end{array}$ & $\begin{array}{c}\text { BLS 92-3, } \\
<100\end{array}$ & $\begin{array}{c}\text { BLS 92-3, } \\
100+\end{array}$ & FH 93 & $\begin{array}{c}\text { Chamber of } \\
\text { Commerce 93 }\end{array}$ & RWJF 93 & $\begin{array}{c}\text { KPMG } \\
96<200\end{array}$ & $\begin{array}{l}\text { KPMG } \\
96200+\end{array}$ & Mercer 97 \\
\hline FFS & 61 & 77 & 78 & 77 & 65 & 57 & 71 & 55 & 33 & 57 & 56 \\
HMO & 21 & 52 & 16 & 14 & 38 & 22 & 53 & 25 & 35 & 73 & 70 \\
PPO & 21 & 46 & 16 & 16 & 31 & 24 & 52 & 38 & 40 & 46 & 63 \\
POS & 2 & & & & & 4 & & & 7 & 35 & 40 \\
\hline
\end{tabular}

Sources: U.S. Chamber of Commerce (1994); Bucci and Grant (1995); EBRI (1995); Cantor, Long, and Marquis (1995); Gabel, Ginsburg, and Hunt (1997); Mercer's Fax Facts (1997).

Note: FH = Foster Higgins, BLS = Bureau of Labor Statistics, RWJF = Robert Wood Johnson Foundation, KPMG = KPMG Peat Marwick, FFS = fee-for-service, $\mathrm{HMO}=$ health maintenance organization, $\mathrm{PPO}=$ preferred provider organization, $\mathrm{POS}$ = point-of-service. 
TABLE 14 Percentage of Firms That Offer and Percentage of Full-Time Employees Offered Different Combinations of Plan Types

\begin{tabular}{|c|c|c|c|c|c|}
\hline & \multicolumn{2}{|c|}{ Percentage of Firms $^{\text {a }}$} & \multirow{2}{*}{$\begin{array}{c}\text { Percentage } \\
\text { of Firms } \\
\text { Mercer } 97\end{array}$} & \multicolumn{2}{|c|}{$\begin{array}{c}\text { Percentage of } \\
\text { Full-Time Workers }\end{array}$} \\
\hline & $<100$ & $100+$ & & $<100$ & $100+$ \\
\hline FFS only & 74 & 44 & 5 & 62 & 32 \\
\hline HMO only & 8 & 8 & 3 & 11 & 6 \\
\hline PPO only & 12 & 18 & 10 & 14 & 15 \\
\hline POS only & & & 4 & 7 & 22 \\
\hline FFS+HMO & 3 & 17 & 8 & 1 & 2 \\
\hline $\mathrm{FFS}+\mathrm{PPO}$ & 1 & 2 & 6 & 3 & 14 \\
\hline FFS+POS & & & 3 & 1 & 9 \\
\hline $\mathrm{HMO}+\mathrm{PPO}$ & 2 & 9 & 14 & & \\
\hline $\mathrm{HMO}+\mathrm{POS}$ & & & 5 & & \\
\hline $\mathrm{PPO}+\mathrm{POS}$ & & & 2 & & \\
\hline $\mathrm{FFS}+\mathrm{HMO}+\mathrm{PPO}$ & $<.5$ & 3 & 14 & & \\
\hline $\mathrm{FFS}+\mathrm{PPO}+\mathrm{POS}$ & & & 2 & & \\
\hline $\mathrm{FFS}+\mathrm{HMO}+\mathrm{POS}$ & & & 10 & & \\
\hline $\mathrm{HMO}+\mathrm{PPO}+\mathrm{POS}$ & & & 6 & & \\
\hline $\mathrm{FFS}+\mathrm{HMO}+\mathrm{PPO}+\mathrm{POS}$ & & & 8 & & \\
\hline
\end{tabular}

Sources: Bucci and Grant (1995); Mercer's Fax Facts (1997).

Note: $\mathrm{FFS}=$ fee-for-service, $\mathrm{HMO}=$ health maintenance organization, $\mathrm{PPO}=$ preferred provider organization, $\mathrm{POS}=$ point-of-service.

a. Using BLS data for 1992-93.

Who is choosing what kind of plan? Not surprisingly, younger workers without long-standing ties to a physician and workers with young children wanting an emphasis on preventive care are more likely to choose HMOs. The 1994 Commonwealth survey found that those with lower incomes are also more likely to choose HMOs, perhaps reflecting a desire for lower OOP expenses (Davis et al., Choice Matters, 1995). However, the 1993 and 1995 Health and Retirement Surveys of workers between the ages of 45 and 64 found the reverse. Those earning less than $\$ 6$ per hour were disproportionately represented in the FFS plans (Johnson and Crystal 1997). The difference may reflect the association between earnings and age. Both studies found that minorities were more likely to choose managed care plans. There are conflicting data on whether there is a connection between health status and selection.

Other plan characteristics are changing as well. Employers are increasing the share of costs paid out of pocket by the employee, both in terms of the 
TABLE 15 Percentage of Privately Insured Population Enrolled in Each Type

\begin{tabular}{lrrrrrr}
\hline & 92 CPS & 93 CPS & $93 / 95$ HRS & 94 CPS & 95 CPS & 95 Harris \\
\hline FFS & 52 & 46 & 40 & 33 & 26 & 50 \\
HMO & 20 & 20 & 29 & 21 & 22 & 23 \\
Staff & 1 & 1 & & 1 & & \\
Group & 5 & 5 & & 6 & & \\
IPA & 8 & 8 & & 9 & & \\
Network & 2 & 1 & & 2 & & \\
Mixed & 3 & 5 & 28 & 2 & 3 & 11 \\
POS & 1 & 1 & 33 & 45 & 49 & 11 \\
PPO & 28 & 33 & 3 & & & \\
Not sure & & & & & & \\
\hline
\end{tabular}

Sources: EBRI (1996); Isaacs (1996); Johnson and Crystal (1997).

Note: CPS = Current Population Survey, HRS $=$ Health and Retirement Survey, FFS $=$ fee-forservice, $\mathrm{HMO}=$ health maintenance organization, IPA = Independent Practice Association, $\mathrm{POS}=$ point-of-service, $\mathrm{PPO}=$ preferred provider organization .

TABLE 16 Percentage of Employees Enrolled in Different Plan Types

\begin{tabular}{lcccccccc}
\hline & 91 & 92 & 93 & 93 & 94 & 95 & 95 & 97 \\
& $H I A A$ & $B_{L} S^{\text {a }}$ St/L & BLS M/L & KPMG & BLS St/L & BLS M/L & KPMG & KPMG \\
\hline FFS & 46 & 43 & 50 & 49 & 38 & 37 & 27 & 18 \\
HMO & 25 & 27 & 23 & 22 & 30 & 27 & 28 & 33 \\
PPO & 22 & 29 & 26 & 20 & 30 & 34 & 25 & 31 \\
POS & 7 & & & 9 & & & 20 & 17 \\
\hline
\end{tabular}

Source: Sullivan et al. (1992); U.S. Department of Labor (1994, 1996, 1997); Jensen and Morrisey (1997); Health Benefits (1997).

a. All BLS figures reported include full-time workers only.

Note: HIAA = Health Insurance Association of America, BLS = Bureau of Labor Statistics, St $/ \mathrm{L}=$ state and local governments, $\mathrm{M} / \mathrm{L}=$ medium and large private establishments, $\mathrm{KPMG}=\mathrm{KPMG}$ Peat Marwick, FFS = fee-for-service, $\mathrm{HMO}=$ health maintenance organization, $\mathrm{PPO}=$ preferred provider organization, $\mathrm{POS}=$ point-of-service.

employer premium contribution and the deductibles and coinsurance rates of the plans offered (U.S. Chamber of Commerce 1994). BLS reports an increase in the number of participating employees who have to contribute to the cost of their individual medical coverage and an increase in the average size of that payment, from $\$ 36$ to $\$ 41$ a month (U.S. Department of Labor, BLS 1997). Another trend is an increase in the number of plans that imposed a deductible 
TABLE 17 Enrollment of Workers When Offered Choice, According to Plan Types Offered

\begin{tabular}{lcccc}
\hline & $F F S$ & $H M O$ & $P P O$ & $P O S$ \\
\hline FFS+HMO & 44 & 56 & & \\
FFS+PPO & 28 & & 72 & \\
FFS+POS & 17 & 43 & 57 & 83 \\
HMO+PPO & & 48 & & 52 \\
HMO+POS & & 34 & 48 & 52 \\
PPO+POS & 20 & 46 & 18 & 63 \\
FFS+HMO+PPO & 19 & 51 & 25 & 24 \\
FFS+PPO+POS & 19 & 36 & 21 & 28 \\
FFS+HMO+POS & & & & \\
HMO+PPO+POS & 15 & & &
\end{tabular}

Source: Mercer's Fax Facts (1997).

Note: FFS = fee-for-service, $\mathrm{HMO}=$ health maintenance organization, $\mathrm{PPO}=$ preferred provider organization, $\mathrm{POS}=$ point-of-service.

and coinsurance payment beginning the first day of a hospitalization. A 1994 survey by the American Management Association found that health care costs for employers who responded to their survey dropped an average of 0.12 percent from the previous year, even though total costs-the sum of employers' and employees' contributions-went up 2.23 percent (Cost Cuts Now 1996). More employers are offering wellness or prevention programs. According to the 1995 BLS survey, 34 percent of full-time employees are now eligible for a wellness program (U.S. Department of Labor, BLS 1997).

\section{CHOICE OF PROVIDER}

The freedom to choose any physician or any hospital was given as the most important reason for choosing a medical plan in a 1993 survey by Hewitt Associates (Key Features 1993). The Chamber of Commerce (1994) estimates that the major health plan offered by approximately one fourth of their survey respondents had limits on a patient's choice of physicians. Several researchers have found that familiarity with the provider and issues of provider choice are important (Grazier et al. 1986; Mechanic, Ettel, and Davis 1990; Tu and Cunningham 1997). In general, FFS and POS plans allow considerably more freedom of provider choice than HMO or PPO plans, both among primary care physicians and between primary care physicians and specialists. The National Ambulatory Medical Care Survey (NAMCS) found that patients in HMOs 
were less likely to have skin care provided by dermatologists (Feldman, Williford, and Fleischer 1996). Linking 1987 National Medical Expenditure Survey ambulatory visit data to American Medical Association data, Cooper, Nichols, and Taylor (1996) found that people enrolled in HMOs see specialists far less often than other patients. Forrest and Reid (1997) analyzed 6 years of data from the NAMCS and estimated that HMO patients were 37 percent less likely to self-refer to a specialist than FFS patients.

The trade-off between provider choice and other attributes, such as OOP costs, varies by population group. Both the tendency to visit specialists and the tendency to join HMOs increase with age and education, and are higher for men (Cooper, Nichols, and Taylor 1996). Mechanic, Ettel, and Davis (1990), in their study of 296 new university employees, found that those selecting the Blue Cross and Blue Shield plan attributed greater importance to freedom of choice of physician, while those selecting an HMO were more likely to give priority to cost consideration and to having services at a single location. The Community Tracking Study found that the majority of adults surveyed in 12 metropolitan areas were willing to trade the ability to choose providers for a reduction in OOP costs (Tu and Cunningham 1997). Not surprisingly, the willingness to trade away choice decreases as income and age increases.

Not all individuals are able to self-select according to the ability to choose any provider. Both the 1993 Employee Health Care Value Survey and the 1994 Commonwealth Survey found that limited choice of physicians led to lower level of satisfaction among managed care plan enrollees (Allen et al. 1994; Davis et al., Choice Matters, 1995). In some cases, this lack of fit between preferences and plan attributes reflects lack of information, or lack of understanding of information given. Garnick et al. (1993) report that in the 1990 New York pilot program, new enrollees in physician networks or HMOs seemed uncertain about restrictions on their choice of hospitals, despite serious efforts on the part of providers to inform them. Less than 40 percent knew that the plan limited choice of hospitals. A 1995 Harris survey estimated that about 25 percent of those enrolled in HMOs or PPOs did not know that their choice of physicians is limited to those in the plan (Isaacs 1996).

\section{How Many People Go Out-of-Network?}

Given the confusion about limitations on provider choice, it is not clear that participants always select the plan that best meets their preferences. Data compiled by KPMG for the American Association of Health Plans (AAHP) 1996 Annual Survey of Employer-Sponsored Health Benefits show that nearly 92 percent of workers with employer-sponsored coverage have the option of a health plan that includes the ability to choose physicians and hospitals outside 
a selected network (Americans with Employer-Sponsored Health Coverage 1996). Among the workers who were offered only one type of plan, 42 percent were offered a PPO, which includes an option for out-of-network coverage.

In the 1993 Kaiser/Commonwealth survey, 40 percent of those insured through their employer are in plans that require additional payments for visits to doctors outside the plan. For those required to pay more to see a doctor outside their plan, 47 percent were very satisfied with the choice of doctors they can see within the plan, 33 percent were somewhat satisfied, 12 percent were not very satisfied, 4 percent were not at all satisfied, and 4 percent were not sure or refused to respond (Davis et al., Health Insurance, 1995). Respondents felt more strongly about losing their choice of a specialist than losing their choice of a general or primary care doctor. The one exception was young adults, who felt most strongly about limited choice of a pediatrician.

We have little data on how many people seek care out of their plan's network, whether that care is partially covered or not covered at all. In the 1994 Commonwealth survey, 17 percent of managed care plan enrollees reported using services outside of their plan in the last 12 months (Davis et al., Choice Matters, 1995). On average, they used four visits per year for services not covered by the plan. The reasons given included wanting to see a better doctor, dissatisfaction with the care received within the plan, convenience, and delay in getting an appointment. The 1995 AAHP Survey reported that 17 percent of HMO enrollees used out-of-network services in POS products (AAHP Annual HMO Industry Survey 1995). There was some variation according to the type of HMO. Only 7 percent of those enrolled in a group model went outof-network, whereas 18 percent in an Independent Practice Association (IPA) model did.

\section{SUMMARY}

In conclusion, what do we know about health and consumer choice? A lot and not very much. There are a lot of data about prevalence of health insurance coverage, kinds of plans offered, and enrollment patterns. We know that the majority of Americans are offered some kind of health insurance plan either through their place of employment or as a dependent on someone else's employer-sponsored health plan. We know that about half of those offered health insurance are offered a choice, usually of only two or three plans. We know that the majority elect to participate in one of those plans. What we know little about, however, is how consumers are making what choices. That is, does the desire for health insurance influence whether to enter the labor market? Are firm type, location, and job content the dominant factors in a worker's choice of where to work and the health insurance plan offered a 
rather minor secondary factor only influential in a ceteris paribus world? Or does the offering of a plan, or multiple plans, often influence that initial decision? Does the type of plan offered matter? Furthermore, what information are consumers given to make these initial choices, or later choices of which plan to choose, or whether to switch? Clearly, there are many interesting questions to ask and issues to discuss before we fully understand the choices and constraints facing health care consumers and the roles played by these options.

\section{APPENDIX \\ Relevant Data Sources}

American Association of Health Plans HMO Industry Survey: annual survey of member health plans.

American Management Association: 1995 survey of 1,100 benefits managers.

Arthur Anderson: 1995 survey of small and mid-sized businesses.

BLS Employee Benefit Survey: surveys of establishments: every two years, on a staggered basis, national survey of medium and large private establishments (100+ employees), small private establishments ( $<100$ employees), and state and local governments.

Commonwealth 1994 Managed Care Survey: Boston, LA, Miami; 500 managed care enrollees and 500 FFSs in each city.

Current Population Survey: annual government survey of national sample of households.

EBRI: 1992 survey of 1,000 nonelderly adults.

Employee Health Care Value Survey: 1993, Xerox, GTE, and Digital Equipment Corp. Surveyed a random sample of their employees $(N=24,306)$ and got a 70 percent completion rate.

Foster \& Higgins: annual survey of employers; 1993 survey of 102 managed care organizations and 127 health care providers.

Harris: 1995 survey of 1,081 adults.

Health and Retirement Survey: 1992 and 1994, University of Michigan Institute for Social Research, national sample of adults aged 45-64.

Hewitt Associates: 1993 Survey of employers.

HIAA surveys: annual from 1987 to 1992; in 1990, 3,192 employers participated.

Kaiser/AHCPR: 1996 national survey of 2,000 adults.

Kaiser/Commonwealth 1993 survey of Americans: 2,006 adults, national survey, 53 percent response rate.

KPMG Peat Marwick: annual surveys since 1993, conducted by National Research Inc., telephone survey; in 1997, 1,502 companies with 200+ employees; Wayne State University collaborated in 1993 and 1995, surveying firms with <200 employees. 
Medical Expenditure Panel Survey: AHCPR began fielding MEPS in March 1996 in conjunction with National Center for Health Statistics (NCHS). Not available yet, expected date for public use tapes was fall 1998. Five components: interviews with household (10,500 families, 24K individuals), nursing home, medical provider, insurance (9,200 employers, 300 union officials, 400 insurers), and insurance (managers at $20 \mathrm{~K}$ establishments).

Mercer 1997 Survey, 283 executives, 34 percent manufacturing, 62 percent services, 4 percent government; 15 percent < 500 employees, 42 percent 501-3,000; 25 percent $3 \mathrm{~K}-10 \mathrm{~K} ; 18$ percent $10 \mathrm{~K}+$.

National Employer Health Insurance Survey: National survey sponsored by NCHS, AHCPR, and the Health Care Financing Administration (HCFA) in 1994. No public use tape released; no published findings.

Robert Wood Johnson Foundation: 10-state survey of businesses in 1993.

Small Business Benefit Survey: survey of businesses with 25 or fewer employees in four sites (1990) and seven sites (1993), conducted by University of Michigan.

U.S. Chamber of Commerce: annual survey since 1961.

Watson Wyatt Worldwide and Washington Business Group on Health: periodic surveys of companies; 1995 survey of 368 companies; 1997 survey of small (<1,000 employees), medium $(1 \mathrm{~K}-10 \mathrm{~K})$, and large $(>10 \mathrm{~K})$ employers.

Note: For further information about some surveys listed in this appendix, see Short (1995).

\section{REFERENCES}

Acs, G., S. H. Long, M. S. Marquis, and P. F. Short. 1996. Self-Insured Employer Health Plans: Prevalence, Profile, Provisions, and Premiums. Health Affairs 15 (2): 266-78.

Allen, H. M., Jr., H. Darling, D. N. McNeill, and F. Bastien. 1994. The Employee Health Care Value Survey: Round One. Health Affairs 13 (4): 25-41.

American Association of Health Plans Annual HMO Industry Survey, 1995. Available: www.aahp.org/menus/index $/ . c f m ? C F I D=80704 \& C F T O K E N=25811$.

Americans with Employer-Sponsored Health Coverage Have Broad Choice of Doctors and Hospitals. 1997. American Association of Health Plans. Press Release, June 24.

Bergman, R. 1994. Study: Employers Consider Cost over Quality in Health Purchases. Hospitals and Health Networks, March 5, 54.

Blankenau, R. 1993. Confused Consumers: When Given Options, What Health Plans Do Consumers Choose-and Why? Hospitals \& Health Networks, July 5, 31-32.

Brown, C., J. Hamilton, and J. Medoff. 1990. Employers Large and Small. Cambridge, MA: Harvard University Press.

Bucci, M., and R. Grant. 1995. Employer-Sponsored Health Insurance: What's Offered; What's Chosen? Monthly Labor Review 118 (10): 38-44.

Buchmueller, T. C. 1996. Marital Status, Spousal Coverage, and the Gender Gap in Employer-Sponsored Health Insurance. Inquiry 33 (4): 308-16.

Buchmueller, T. C., and P. J. Feldstein. 1997. The Effect of Price on Switching among Health Plans. Journal of Health Economics 16:231-47. 
Cantor, J. C., S. H. Long, and M. S. Marquis. 1995. Private Employment-Based Insurance in Ten States. Health Affairs 14 (2): 199-211.

Chernew, M. E., and D. P. Scanlon. 1998. Health Plan Report Cards and Insurance Choice. Inquiry 35 (1): 9-22.

Cooper, P. F., and A. Monheit. 1993. Does Employment-Related Health Insurance Inhibit Job Mobility? Inquiry 30 (Winter): 400-416.

Cooper, P. F., L. M. Nichols, and A. K. Taylor. 1996. Patient Choice of Physician: Do Health Insurance and Physician Characteristics Matter? Inquiry 33:237-46.

Cooper, P. F., and B. Steinberg Schone. 1997. More Offers, Fewer Takers for Employment-Based Health Insurance: 1987 and 1996. Health Affairs 16 (6): 142-49.

Cost Cuts Now, Quality Later. 1996. Hospitals $\mathcal{E}$ Health Networks, February 5, 15.

Davis, K., K. S. Collins, C. Schoen, and C. Morris. 1995. Choice Matters: Enrollees' Views of Their Health Plans. Health Affairs 14 (2): 99-112.

Davis, K., D. Rowland, D. Altman, K. S. Collins, and C. Morris. 1995. Health Insurance: The Size and Shape of the Problem. Inquiry 32:196-203.

Ellis, R. P. 1989. Employee Choice of Health Insurance. Review of Economics and Statistics 71 (2): 215-23.

Employee Benefit Research Institute (EBRI). 1995. EBRI Databook on Employee Benefits. 3d ed. Washington, DC: Employee Benefit Research Institute.

- 1996. Health Insurance Enrollment by Plan Type, 1992-1995. FACTS from EBRI. Washington, DC: Employee Benefit Research Institute.

- 1997. Fundamentals of Employee Benefit Programs. 5th ed. Washington, DC: Employee Benefit Research Institute.

Employers. 1996. Hospitals \& Health Networks, January 5, 17.

Evans, A. 1995. The Federal Employees Health Benefits Program, Managed Competition, and Considerations for Medicare. Report. National Academy on Aging, Washington, DC, September.

Feldman, R., M. Finch, B. Dowd, and S. Cassou. 1989. The Demand for EmploymentBased Health Insurance Plans. Journal of Human Resources 24 (1): 115-42.

Feldman, S. R., P. M. Williford, and A. B. Fleischer Jr. 1996. Lower Utilization of Dermatologists in Managed Care: Despite Growth in Managed Care, Visits to Dermatologists Did Not Decrease: An Analysis of National Ambulatory Medical Care Survey Data, 1990-1992. Journal of Investigative Dermatology 107 (6): 860-64.

Forrest, C. B., and R. J. Reid. 1997. Passing the Baton: HMOs' Influence of Referrals to Specialty Care. Health Affairs 16 (6): 157-62.

Francis, W. 1995. The Political Economy of the Federal Employees Health Benefits Program. In Health Policy Reform, ed. Robert Helms, 269-307. Washington, DC: AEI.

Fronstin, P. 1997. Trends in Health Insurance Coverage. EBRI Issue Brief 185:1-18.

Gabel, J. R., P. B. Ginsburg, and K. A. Hunt. 1997. Small Employers and Their Health Benefits, 1988-1996: An Awkward Adolescence. Health Affairs 16 (5): 103-10.

Garnick, D. W., A. M. Hendricks, K. E. Thorpe, J. P. Newhouse, K. Donelan, and R. J. Blendon. 1993. How Well Do Americans Understand Their Health Coverage? Health Affairs, fall, 204-12. 
Gawande, A. A., R. J. Blendon, M. Brodie, J. M. Benson, L. Levitt, and L. Hugick. 1998. Does Dissatisfaction with Health Plans Stem from Having No Choices? Health Affairs 17 (5): 184-94.

Getting What You Pay For: Purchasing Value in Health Care. 1997. Medical Benefits, July $15,3$.

Ginsburg, P. B., J. R. Gabel, and K. A. Hunt. 1998. Tracking Small-Firm Coverage, 19891996. Health Affairs 17 (1): 167-71.

Grazier, K. L., W. C. Richardson, D. P. Martin, and P. Diehr. 1986. Factors Affecting Choice of Health Care Plans. Health Services Research 20:659-82.

Gruber J., and B. C. Madrian. 1993. Limited Insurance Portability and Job Mobility: The Effects of Public Policy on Job-Lock. National Bureau of Economic Research Working Paper No. 4479, September.

Health Benefits 1997. 1997. Medical Benefits 14 (13): 1-2.

Hibbard, J., and J. J. Jewett. 1996. What Type of Quality Information Do Consumers Want in a Health Care Report Card? Medical Care Research and Review 53 (1): 28-47.

Hibbard, J., J. J. Jewett, M. W. Legnini, and M. Tusler. 1997. Choosing a Health Plan: Do Large Employers Use the Data? Health Affairs 16 (6): 172-80.

Hoerger, T. J., and L. Howard. 1995. Search Behavior and Choice of Physician in the Market for Prenatal Care. Medical Care 33 (4): 332-49.

Hunt, K. A., S. J. Singer, J. Gabel, D. Liston, and A. C. Enthoven. 1997. Paying More Twice: When Employers Subsidize Higher-Cost Health Plans. Health Affairs 16 (6): 150-56.

Isaacs, S. 1996. Consumers' Information Needs: Results of a National Survey. Health Affairs 15 (4): 31-41.

Jensen, G. A., and M. A. Morrisey. 1997. Managed Care and the Small Group Market. Paper presented at American Enterprise Institute, Managed Care and Changing Health Care Markets conference, April 10, Washington, DC.

Jensen, G. A., M. A. Morrisey, S. Gaffney, and D. K. Liston. 1997. The New Dominance of Managed Care: Insurance Trends in the 1990s. Health Affairs 16 (1): 125-36.

Johnson, R. W., and S. Crystal. 1997. Health Insurance Coverage at Midlife: Characteristics, Costs, and Dynamics. Health Care Financing Review 18 (3): 123-38.

Key Features of Employee Health Benefits Plan. 1993. Hospitals E Health Networks, June 5,66 .

Larger Firms Most Concerned with Quality. 1996. Hospitals \& Health Networks, April 20, 11.

Lippert, C., and E. Wicks. 1991. Critical Distinctions: How Firms That Offer Health Benefits Differ from Those That Do Not. Report. Health Insurance Association of America, Washington, DC.

Long, S. H., and M. S. Marquis. 1993. Gaps in Employer Coverage: Lack of Supply or Demand? Health Affairs 12 (Suppl.): 282-93.

- 1998. How Widespread Is Managed Competition? Data Bulletin: Results from the Community Tracking Study Number 12 (summer). Center for Studying Health System Change, Washington, DC. 
Madrian, B. C. 1993. Employment-Based Health Insurance and Job Mobility: Is There Evidence of Job-Lock? National Bureau of Economic Research Working Paper No. 4476, September.

McLaughlin, C. G., and W. K. Zellers. 1992. Shortcomings of Voluntarism in the SmallGroup Market. Health Affairs 11 (2): 28-40.

- 1994. Small Business and Health Care Reform: Understanding the Barriers to Employee Coverage and Implications for Workable Solutions. Ann Arbor: University of Michigan Press.

Mechanic, D. 1989. Consumer Choice among Health Insurance Options. Health Affairs 8 (1): $138-48$.

Mechanic, D., T. Ettel, and D. Davis. 1990. Choosing among Health Insurance Options: A Study of New Employees. Inquiry 27:14-23.

Mercer's Fax Facts Surveys: HMOs. 1997. Available: www.mercer.com/hr/ news/fax_facts_hmos.html.

Morrisey, M. A., G. A. Jensen, and R. J. Morlock. 1994. Small Employers and the Health Insurance Market. Health Affairs 13 (5): 149-61.

Neipp, J., and R. Zeckhauser. 1985. Persistence in the Choice of Health Plans. In Advances in Health Economics and Health Services Research. Vol. 6, ed. R. M. Scheffler and L. F. Fossiter, 47-72. Greenwich, CT: JAI.

Nichols, L. M., L. J. Blumberg, G. P. Acs, C. E. Uccello, and J. A. Marsteller. 1997. Small Employers: Their Diversity and Health Insurance. Washington, DC: Urban Institute. Available: www.urban.org.

Pauly, M. V. 1997. Health Benefits at Work: An Economic and Political Analysis of Employment-Based Health Insurance. Ann Arbor: University of Michigan Press.

Robinson, J. C., L. B. Gardner, and H. S. Luft. 1993. Health Plan Switching in Anticipation of Increased Medical Care Utilization. Medical Care 31 (1): 43-51.

Robinson, S., and M. Brodie. 1997. Understanding the Quality Challenge for Health Consumers: The Kaiser/AHCPR Survey. Joint Commission Journal on Quality Improvement 23 (5): 239-44.

Scanlon, D. P., M. E. Chernew, and J. R. Lave. 1997. Consumer Health Plan Choice: Current Knowledge and Future Directions. Annual Review of Public Health 18:507-28.

Schoen, C., and L. Zacharis. 1994. Federal and State Public Employees Health Benefits Programs. In Critical Issues in U.S. Health Reform, ed. Eli Ginzberg, 208-53. Boulder, CO: Westview.

Schuttinga, J. A., M. Falik, and B. Steinwald. 1985. Health Plan Selection in the Federal Employees Health Benefits Program. Journal of Health Politics, Policy and Law 10 (1): 119-39.

Schweitzer, M., J. C. Hershey, and D. A. Asch. 1996. Individual Choice in Spending Accounts: Can We Rely on Employees to Choose Well? Medical Care 34 (6): 583-93.

Sherer, J. L. 1993. What Are Employee Benefits Worth-To Employees? Hospitals, May $20,56$.

Short, P. F. 1995. Data Sources for Studies of Self-Insured Health Plans. Santa Monica, CA: RAND. 
Sullivan, C. B., M. Miller, R. Feldman, and B. Dowd. 1992. Employer-Sponsored Health Insurance in 1991. Health Affairs 11 (4): 172-85.

Tu, H., and P. Cunningham. 1997. Strong Opinions Held about the Tradeoff between Choice of Providers and Cost of Care. Data Bulletin: Results from the Community Tracking Study Number 4 (fall). Center for Studying Health System Change, Washington, DC.

Tumlinson, A., H. Bottigheimer, P. Mahoney, E. M. Stone, and A. Hendricks. 1997. Choosing a Health Plan: What Information Will Consumers Use? Health Affairs 16 (3): 229-38.

U.S. Chamber of Commerce Research Center. 1994. Employee Benefits: Survey Data from Benefit Year 1993. Washington, DC: U.S. Chamber of Commerce.

U.S. Department of Labor, Bureau of Labor Statistics (BLS). 1997. Employee Benefits in Medium and Large Private Establishments, 1995. Washington, DC: U.S. Department of Labor.

. 1994. Employee Benefits in State and Local Governments, 1992. Bulletin 2444, July. Washington, DC: U.S. Department of Labor.

- 1996. Employee Benefits in Small Private Establishments, 1994. Bulletin 2475, April. Washington, DC: U.S. Department of Labor.

. 1996. Employee Benefits in State and Local Governments, 1994. Bulletin 2477. Washington, DC: U.S. Department of Labor.

—. 1995. Employee Benefits in Medium and Large Private Establishments, 1993, 1994. Washington, DC: U.S. Department of Labor.

U.S. General Accounting Office (GAO). 1992. Employer-Based Health Insurance: High Costs, Wide Variation Threaten System. Report, GAO/HRD-92-125, September.

- 1995. Health Care: Employers and Individual Consumers Want Additional Information on Quality. Report, GAO/HEHS-95-201.

_ 1996. Health Insurance: Millions Relying on Individual Market Face Cost and Coverage Trade-offs. Report, GAO/HEHS-97-8.

Wilensky, G. R. 1995. Some Thoughts on Choice and Satisfaction. Health Affairs 14 (2): 113.

Yakoboski, P., P. Fronstin, S. Snider, A. Reilly, D. Scheer, B. Custer, and S. Boyce. 1994. Employment-Based Health Benefits: Analysis of the April 1993 Current Population Survey. EBRI Issue Brief 152:1-50.

Zellers, W. K., C. G. McLaughlin, and K. D.Frick. 1992. Health Insurance for Small Businesses: Only the Healthy Need Apply. Health Affairs 11 (1): 174-80. 